Journal of Accident and Emergency Medicine 1994 11, 49-51

\title{
The effect of legislation on injuries sustained by rear seat car passengers
}

\author{
I.G. KENDALL \& G.G.BODIWALA \\ Department of Accident \& Emergency Medicine, Leicester Royal Infirmary, Leicester
}

\section{SUMMARY}

A study of 206 injured rear seat passengers was undertaken over two 4-month periods before and after the introduction of legislation enforcing use of rear seat-belts on 1 July 1991. The proportion of both adults and children using rear seat-belts increased after the law. Those wearing belts were less likely to suffer serious injury. The majority of passengers comply with the law but many rear seat passengers remain unrestrained because cars are not fitted with belts.

Key words: injury, legislation, rear seat passenger, seat-belts.

\section{INTRODUCTION}

A previous study from this department ${ }^{1}$ demonstrated that most injuries to unrestrained rear seat passengers were due to contact with the front seat, glazing materials or other parts of the car. It was concluded that many of these injuries would be prevented if rear seat passengers used suitable restraining systems. The effectiveness of seat-belts in reducing ejection ${ }^{2}$ and injury to rear seat passengers has been documented elsewhere. ${ }^{3}$

Legislation enforcing front seat-belt use in the UK on 1 February 1983 was an immediate success in increasing seat-belt use and reducing the number of fatal and serious injuries to front seat occupants in those complying with the new law. ${ }^{4-7}$

Use of appropriate rear seat restraint, where fitted and available, has been required by law in children (under the age of 14) since September 1989. A law

Correspondence:

I.G. Kendall Consultant in Accident \& Emergency Medicine, Princess Margaret Hospital, Swindon, SN1 4JN passed on 1 July 1991 required, in addition, compulsory use of rear seat-belts, where fitted, by adults (those over 14 years).

We wished to observe the effect of the new law on injuries presenting to our accident and emergency (A\&E) department. We also attempt to answer why many rear seat passengers remain unrestrained.

\section{METHODS}

All rear seat car occupants involved in road traffic accidents (RTAs) and attending the A\&E department of the Leicester Royal Infirmary between 1 March 1991 and 31 October 1991 were identified and the A\&E and hospital notes together with the pre-hospital record of those who had arrived by ambulance were examined. In those cases where no seat-belt was worn patients were sent a postal questionnaire in which the respondent could be identified by number only. The questionnaire asked if a belt was worn, the type of belt used, and the reason for not wearing a restraint device.

\section{RESULTS}

A total of 2339 people were seen and treated in the A\&E department as a result of RTAs during the study period. Injuries sustained in cars accounted for 1398 attendances and of these 242 were rear seat passengers. Thirty-six rear seat passengers had to be excluded because of insufficient data on seat-belt use, leaving 206 for study.

\section{Use of restraint}

Of the $\mathbf{2 0 6}$ patients under study a total of 86 wore restraints, 120 did not. Average rate of use of belts in those attending the department was $30 \%$ before the law was introduced and $53 \%$ after. A monthly breakdown of adult belt use is shown in Fig. 1 . Eighty-two patients were under the age of $14(40 \%)$. The use of restraints by childiren was higher than in adults both before and after legislation (see Table 1).

\section{Reasons for not wearing a belt}

Results from the postal questionnaire are shown in Table 2. In the majority of cases amongst the replies received, cars were not fitted with belts: 
I.G. Kendall \&

G.G. Bodiwala

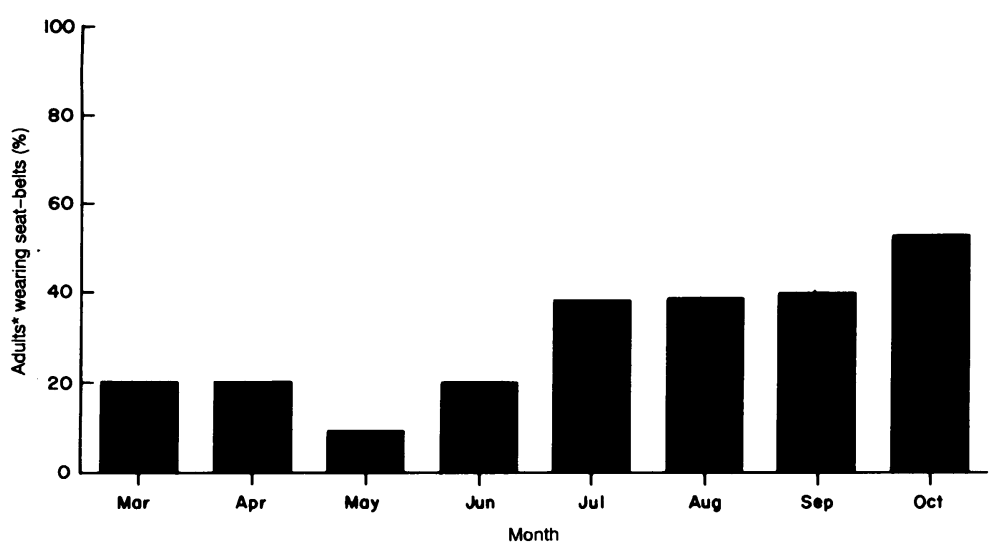

Table 1. Use of restraints by rear seat passengers

\begin{tabular}{lcc}
\hline & Restrained (\%) & Total \\
\hline Before law (child) & $18(49 \%)$ & 37 \\
Before law (adult) & $11(18 \%)$ & 61 \\
After law (child) & $30(67 \%)$ & 45 \\
After law (adult) & $27(43 \%)$ & 63 \\
\hline
\end{tabular}

Table 2. Reasons for not wearing belts

\begin{tabular}{lr}
\hline Reason & Number \\
\hline Belt not fitted in car & 67 \\
Forgot & 5 \\
Dislike & 3 \\
Exempt & 2 \\
Other & 4 \\
No reply received & 39 \\
Total & 120 \\
\hline
\end{tabular}

\section{Types of injury}

Injury distribution

\section{DISCUSSION}

Fig. 1. Percentage of adults ( $* 14$ years + ) wearing seat-belts (law introduced 1 July 1991).

The types of injury recorded, and the disposal of the patients from the Department are shown in Table 3.

Table 4 shows the injury distribution for those wearing belts or not wearing belts in further detail.

This small study demonstrates that restrained rear seat passengers are less likely to suffer injury or death than those who did not wear belts. Legislation enforcing the use of the rear belts appears to have been successful in increasing belt use, but an unacceptably high proportion of rear seat passengers remain unrestrained. This appears to be because belts are not fitted in older cars.

Cars sold in the UK after October 1986 have

\section{No belt worn \\ (Total 120 patients)}

No injury found

Admitted to hospital

Deaths after

admission

Internal injuries

Discharged no follow

up in hospital

Number of wounds

Number of fractures

Number of soft tissue injuries
Table 3. Summary of injuries and disposal.

$\begin{array}{lc}5(4 \%) & 17(20 \%) \\ 14(12 \%) & 8(9 \%) \\ 3 & 1 \\ 4 & 1 \\ 87(73 \%) & 76(88 \%) \\ 29 & 29 \\ 20 & 5 \\ 98 & 88\end{array}$




\begin{tabular}{lcccr}
\hline $\begin{array}{l}\text { Site of } \\
\text { injury }\end{array}$ & $\begin{array}{c}\text { No belt } \\
\text { (120 patients) }\end{array}$ & $\%$ & $\begin{array}{c}\text { Belt worn } \\
\text { (86 patients) }\end{array}$ & $\%$ \\
\hline Head & 63 & 52.5 & 50 & 58.1 \\
Neck & 17 & 14.2 & 22 & 25.6 \\
Upper limb & 26 & 21.7 & 10 & 11.6 \\
Chest & 3 & 2.5 & 9 & 10.5 \\
Trunk & 8 & 6.7 & 5 & 5.8 \\
Lower limb & 30 & 30 & 9 & 10.5 \\
\hline
\end{tabular}

Table 4. Injuries by site

been fitted with rear seat-belts at manufacture. Rear seat-belt anchor points have been installed in all UK cars at production since 1982. Legislation demanding the fitting of suitable restraints for all rear seat passengers might further reduce the number and severity of injuries sustained. Publicity promoting use of rear seat-belts might be better aimed at those who drive cars with no suitable restraints fitted in the rear seat. They could be easily identified at the yearly MOT testing already required in older cars.

\section{REFERENCES}

1. Bodiwala G.G., Thomas P.D. \& Otubushin A. (1989) Protective effect of rear-seat restraints during car collisions. Lancet (i) 8634, 369-371.

2. Green P.D., Robertson N.K.B., Bradford M.A. \&
Bodiwala G.G. (1987) Car occupant ejection in 919 sample accidents in the UK, 1983-86. Society of Automotive Engineers International Congress and Exposition, Warrendale, Pennsylvania (SAE paper 870323).

3. Christian M.S. \& Bullimore D.W. (1989) Reduction in injury severity in rear seat passengers using restraints. Injury 20, 262-264.

4. Christian M.S. (1984) Morbidity and mortality of car occupants: Comparative study over 24 months. British Medical Journal 289, 1525-1526.

5. Allen M.J., Barnes M.R. \& Bodiwala G.G. (1985) The effect of seat-belt legislation on injuries sustained by car occupants. Injury 16, 471-476.

6. Dreghorn C.R. (1985) The effect of seat belt legislation on a District General Hospital. Injury 16, 415-418.

7. Rutherford W.H., Greenfield A.A., Hayes H.R.M. \& Nelson J.K. (1985) The Medical Effects of Seat Belt Legislation in the UK. HMSO, London. 